\title{
Analiza zastosowania wymogów formalnych i merytorycznych w tłumaczeniu poświadczonym na przykładzie studenckiego przekładu polskiego i niemieckiego wyroku rozwodowego
}

\author{
Applying formal and content-related principles of certified translation exemplified in students' \\ translation of a Polish and German divorce decree: an analysis
}

\author{
Joanna MIREK \\ Katolicki Uniwersytet Lubelski Jana Pawła II/ The John Paul II Catholic University \\ of Lublin \\ E-mail: joannamirek@kul.pl,
}

\begin{abstract}
Undoubtedly, correct translation of legal texts is considered one of the most demanding challenges for translators. Moreover, exclusively certified translation produced by sworn translators is deemed legally binding. The object of the analysis are two divorce decrees - a Polish and a German one, respectively, which were excerpted from the book by Iluk and Kubacki (2006) and translated by the second-degree Students of Applied Linguistics at Maria Curie-Skłodowska University in Lublin, who at that point had already received two years of intensive training in legal translation. It was tested whether both formal and content-related principles of certified translation were followed by juxtaposing the students' translation with the model certified translation published by Dahlmanns and Kubacki (2014), who are considered experts in this field. The results proved to be satisfactory, however, they also depict major difficulties, which are - in the vast majority of cases - typical of beginning translators.
\end{abstract}

Keywords: certified translation, sworn translators, formal and content-related principles, divorce decrees, comparative law

\section{Wstęp}

W niniejszym artykule przedstawiono wyniki analizy pilotażowego projektu przeprowadzonego na grupie studentów pierwszego roku drugiego stopnia lingwistyki stosowanej Uniwersytetu Marii Curie-Skłodowskiej, polegającego na sporządzeniu przez nich pisemnego przekładu poświadczonego niemieckiego i polskiego wyroku rozwodowego. Badanie zostało przeprowadzone w warunkach analogicznych do pisemnej części egzaminu na tłumacza przysięgłego. Celem niniejszych rozważań jest przedstawienie, w jakim stopniu adepci thumaczenia zastosowali się do wymogów formalnych i merytorycznych dotyczących tego rodzaju przekładu, a także zaprezentowanie wstępnych implikacji dydaktycznych. Część teoretyczna obejmuje zwięzłą charakterystykę tłumaczenia poświadczonego oraz opis wymagań stawianych przed kandydatami na tłumaczy przysięgłych w zakresie tłumaczenia pisemnego, które też służą jako kryteria analizy studenckich przekładów. W części empirycznej przedstawiono wyniki badania wraz z analizą opatrzoną wnioskami i wskazówkami ukierunkowanymi na potrzeby dydaktyków tego rodzaju przekładu. 


\section{Istota thumaczenia poświadczonego}

Ustawa o zawodzie thumacza przysięgłego z 25 listopada 2004 (Dz. U. Nr. 273, poz. 2702 z późn.zm. $)^{1}$ stanowi podstawę prawną do wykonywania tego zawodu. Sporządzone przez tłumacza przysięgłego thumaczenie nazywane jest poświadczonym. Do prawnie ustanowionych zadań tłumaczy przysięgłych należy zarówno przekład pisemny dokumentów tj. wyroki, akty oskarżenia, umowy, wezwania sądowne itd., jak i ustny np. podczas rozpraw sądowych, przesłuchania czy sporządzania aktów notarialnych (zob. A.D. Kubacki 2009: 12). Z racji tego, że przekład poświadczony wywiera określone skutki prawne, na thumaczach przysięgłych spoczywają określone ustawą obowiązki. Mianowicie, każdy thumacz przysięgły jest ustawowo zobowiązany do zachowania poufności w zakresie wszelkich okoliczności i faktów, z którymi zapoznał się podczas wykonywania swojej pracy (art. 14 pkt 2 Ustawy; A.D. Kubacki 2010: 279). Jest także zobowiązany do wykonywania powierzonych mu zadań ze szczególną starannością i bezstronnością z poszanowaniem przepisów prawa (art. 14 pkt 1 Ustawy) $)^{2}$. Nie wolno mu także odmówić świadczenia usług dla organów państwowych (sądy, prokuratura, policja, organy administracji publicznej) bez ważnej przyczyny uzasadniającej tej odmowę (art. 15 Ustawy). Ponadto zobowiązany jest do prowadzenia repertorium (art. 17 ust. 1 Ustawy), sporządzenia thumaczenia według nakazanych ustawowo reguł oraz do doskonalenia swoich kwalifikacji zawodowych (art. 14 pkt 2 Ustawy; tamże), co wynika z odpowiedzialności zawodowej thumaczy przysięgłych.

K.E.W. Fleck (1999: 231) definiuje tłumaczenie poświadczone jako każdy przekład myśli wyrażonej w języku obcym znajdującej zastosowanie w obrocie prawnym języka docelowego zamiast dokumentu oryginalnego. Do sporządzenia tego rodzaju thumaczenia uprawniony jest wyłącznie tłumacz przysięgły (zob. tamże). Natomiast K. Jessnitzer (1992: 2 i nast.) natomiast określa ten zawód jako thumacza dokumentacji i upatruje jego zadania w thumaczeniu, względnie uwierzytelnianiu thumaczenia $\mathrm{z}$ języka obcego lub na język obcy dla celów wyznaczonych przez sądy lub urzędy (zob. tamże). W kontekście polskim tłumaczenie poświadczone definiowane jest jako szczególny rodzaj przekładu specjalistycznego, które sporządzane jest przez thumacza przysięgłego, przez niego podpisane i opatrzone jego pieczęcią (K. Dahlmanns/ A.D. Kubacki 2014: 21). Sam thumacz przysięgły uznawany jest za osobę o nieposzlakowanej opinii, odznaczającą się uczciwością, kompetentną pod względem językowym i merytorycznym, która została powołana do wykonywania tego zawodu przez organ państwowy. Tłumaczenie poświadczone może być wyłącznie sporządzone w formie pisemnej (wydruku). Zlecane jest ono przede wszystkim przez organy i instytucje państwowe, tj. sądy, prokuraturę, policję, itp. (zob. tamże). Zgodnie z Kodeksem tlumacza przysięglego (D. Kierzowska i in. 2018: 7) przedmiotem thumaczenia poświadczonego są dokumenty. Tłumacz zobowiązany jest do doprecyzowania w

\footnotetext{
${ }^{1} \mathrm{http}: / /$ isap.sejm.gov.pl/DetailsServlet?id=WDU20042732702 [Pobrano 10.01.2017].

${ }^{2}$ Art. 14. 1. Tłumacz przysięgły jest obowiązany do: 1) wykonywania powierzonych mu zadań ze szczególną starannością i bezstronnością, zgodnie z zasadami wynikającymi z przepisów prawa $[\ldots]$.
} 
formule poświadczającej, czy dokument ma formę oryginału czy odpisu (zob. tamże).

Tłumaczenie sporządzone przez tłumacza przysięgłego uznawane jest jako gwarant wiernego przekładu tekstu oryginalnego. Tym samym thumacz ponosi pełną odpowiedzialność za dokonany przez siebie przekład, który winien być obiektywny, wierny i precyzyjny, co potwierdza thumacz swoim podpisem zgodnie ze złożoną przysięgą (zob. A.D. Kubacki 2012: 111 i nast.). A. Pisarska i T. Tomaszkiewicz (1999, w: K. Dahlmanns/ A.D. Kubacki 2014: 22) podkreślają, że tłumacz przysięgły ponosi pełną odpowiedzialność za jakość sporządzonego przez siebie przekładu, w związku z czym nie wolno mu w sposób świadomy zmieniać sensu oryginału. Składając podpis i pieczęć okrągłą pod swoim tłumaczeniem oświadcza on, że jego przekład jest wierny oryginałowi oraz że tłumaczenie staje się formalnie prawnie wiążącym dokumentem, który wywiera określone skutki prawne (tamże).

Przekład poświadczony ma charakter sformalizowany (zob. R. Solová 2010, w: K. Dahlmanns/ A.D. Kubacki 2014: 27). Każde tego typu tłumaczenie zawiera obligatoryjnie formułę poświadczającą, która świadczy o skonwencjonalizowanym charakterze tego rodzaju przekładu. Formuła zawiera informacje o zgodności z formą przedłożonego dokumentu (kopia, skan, oryginał). Pod spodem znajduje się miejsce na odcisk pieczęci okrągłej tłumacza, zawierającej jego dane identyfikacyjne. Obok umieszcza się informację o miejscu i dacie sporządzenia thumaczenia, a także podpis tłumacza. Należy również zaznaczyć, że przekład poświadczony zawiera nie tylko tłumaczenie samego tekstu wejściowego, ale też opis wszelkich elementów graficznych mu towarzyszących (tj. odciski pieczęci, podpisy, parafy itd.) lub nieobecnych w tekście, na które jednak przygotowano miejsce (np. rubryki formularza). W takich przypadkach thumacz zobowiązany jest do umieszczenia stosownej uwagi o niewypełnionej rubryce. Szczegółowe zasady sporządzania tłumaczenia poświadczonego omówiono w dalszej części artykułu.

Należy również wspomnieć, że w świetle art. 204 Kodeksu postępowania karnego $^{3}$, thumacz traktowany jest jako biegły, a poprawnie sporządzone thumaczenie poświadczone wywołuje odpowiednie skutki prawne w systemie prawnym języka docelowego. Polski ustawodawca oczekuje zatem, że zawód tłumacza przysięgłego powinien być wykonywany jedynie przez najlepiej wykwalifikowanych thumaczy. Fakt, że tłumacze przysięgli traktowani są jako biegli sądowi i że zapewniony zostaje im dostęp do akt sprawy świadczy o wysokim statusie tego zawodu. W pełni uzasadnia to wysokie wymagania stawiane przed kandydatami na thumaczy przysięgłych oraz stopień trudności egzaminu. W tym miejscu warto również zaznaczyć, że zawód thumacza przysięgłego posiada status zawodu zaufania publicznego (zob. A.D. Kubacki 2010: 275).

\footnotetext{
${ }^{3}$ Art. 204. § 1. Należy wezwać tłumacza, jeżeli zachodzi potrzeba przesłuchania: 1) głuchego lub niemego, a nie wystarcza porozumienie się z nim za pomocą pisma, 2) osoby nie władającej językiem polskim. $\S 2$. Należy również wezwać tłumacza, jeżeli zachodzi potrzeba przełożenia na język polski pisma sporządzonego w języku obcym lub odwrotnie albo zapoznania oskarżonego z treścią przeprowadzanego dowodu. § 3. Do thumacza stosuje się odpowiednio przepisy dotyczące biegłych.
} 


\section{Egzamin na thumacza przysięglego}

Kandydat na thumacza przysięgłego musi spełniać wymagania określone wspomnianą Ustawą (zob. A.D. Kubacki 2014: 31 i nast.) oraz pozytywnie zdać egzamin państwowy przy Ministerstwie Sprawiedliwości w Warszawie, którego przebieg został doprecyzowany w odnośnym Rozporządzeniu ${ }^{4}$. Egzamin przeprowadzany jest przez powołaną do tego celu Państwową Komisję Egzaminacyjną, której skład i działalność uregulowana jest ustawą o zawodzie tłumacza przysięgłego. Egzamin składa się z części pisemnej i ustnej, przy czym dopuszczenie kandydata do części ustnej warunkowane jest pozytywnym złożeniem egzaminu z części pisemnej. Cały egzamin uznaje się za zdany, jeżeli obydwie części zostaną pozytywnie zaliczone. Przebieg egzaminu jest ściśle określony. Dla celów niniejszego artykułu zostanie opisany przebieg jedynie części pisemnej, ponieważ w badaniu nie przeprowadzono analizy thumaczenia ustnego.

Część pisemna trwa maksymalnie cztery godziny zegarowe i obejmuje thumaczenie czterech tekstów - dwóch na język obcy i dwóch na język polski. Dozwolone jest korzystanie z własnych glosariuszy i słowników z wyłączeniem wzorów pism, podręczników, tekstów aktów prawnych i ich przekładu itp. (zob. A.D. Kubacki 2014: 32). Teksty podlegające thumaczeniu mają charakter urzędowy, prawniczy, a także dotyczycący gospodarki i tematyki społeczno-politycznej. Wszystkie egzaminy zostają stosownie zakodowane, co stanowi gwarancję anonimowości (zob. A.D. Kubacki 2010: 276). Maksymalna liczba punktów za każdą część egzaminu wynosi 200, zaś egzamin uznaje się za zdany przy wyniku co najmniej $75 \%$. Pozytywna ocena egzaminu jest jednoznaczna $\mathrm{z}$ oceną komisji, że kandydat jest w stanie przedstawić stan faktyczny w komunikacji międzynarodowej i międzykulturowej w języku docelowym w sposób odpowiadający funkcji tekstu wyjściowego (A.D. Kubacki 2009: 14, K. Nartowska 2015: 11). Z danych statystycznych wynika, że średnio około jedna czwarta kandydatów zdaje egzamin ze skutkiem pozytywnym (zob. A.D. Kubacki 2012: 191 i nast.). Tak niski odsetek zdawalności można upatrywać zdaniem A.D. Kubackiego (zob. 2009: 15) przede wszystkim w niedostatecznym przygotowaniu kandydatów. Komisja upatruje główne źródła deficytów w nieznajomości terminologii prawniczej, błędach dotyczących składni, słowotwórstwa tekstów specjalistycznych oraz wybrakowanej wiedzy ogólnej oraz brakach kompetencji gramatycznych kandydatów (zob. tamże).

Kolejna część artykułu poświęcona jest właściwej analizie wyników badania przeprowadzonego na grupie studentów pod względem spełniania formalnych i merytorycznych zasad sporządzania tłumaczeń poświadczonych.

\section{Projekt}

W poniższej części zawarto opis realizacji projektu pilotażowego przeprowadzonego

${ }^{4}$ Rozporządzenie Ministra Sprawiedliwości z dnia 24 stycznia 2005 r. w sprawie szczegółowego sposobu przeprowadzania egzaminu na thumacza przysięgłego (Dz.U. nr 15, poz. 129). http://prawo.sejm.gov.pl/isap.nsf/DocDetails.xsp?id=WDU20050150129 [Pobrano 10.01.2019]. 
na grupie studentów studiów pierwszego roku drugiego stopnia lingwistyki stosowanej Uniwersytetu Marii Curie-Skłodowskiej w kombinacji językowej niemiecki z angielskim. W dalszej części przeanalizowano przekład studencki pod względem przestrzegania wymogów formalnych i merytorycznych dotyczących tłumaczenia poświadczonego. Następnie podsumowano wyniki badania i przedstawiono wnioski wraz z implikacjami dydaktycznymi.

\subsection{Korpus badawczy oraz metodologia}

Projekt pilotażowy, o którym mowa w niniejszym rozdziale, obejmował przetłumaczenie przez studentów pierwszego roku drugiego stopnia lingwistyki stosowanej UMCS (w kombinacji z językiem niemieckim jako wiodącym oraz angielskim jako towarzyszącym) dwóch wyroków rozwodowych - polskiego i niemieckiego. Łączna liczba studentów, którzy wzięli udział w badaniu wynosiła siedem ${ }^{5}$. W chwili przeprowadzenia badania studenci mieli już za sobą dwa lata edukacji w zakresie tłumaczenia specjalistycznego z języka niemieckiego. Przedmiot ten był prowadzony przez doświadczonego thumacza przysięgłego. Tematyka zajęć skupiona była wokół sporządzenia tłumaczenia poświadczonego, które spełnia kryteria wymagane na egzaminie dla kandydatów na thumacza przysięgłego. W związku z tym studenci byli zaznajomieni zarówno z formalnymi i merytorycznymi kryteriami dotyczącymi sporządzania tego rodzaju thumaczenia, zasadami oceniania egzaminu na thumacza przysięgłego, jak i poprawnym użyciem polskiego i niemieckiego języka prawnego i prawniczego. Ponadto zaś w trakcie kursu zostali wprowadzeni w tematykę sądownictwa i prawa cywilnego w Niemczech i Polsce ze szczególnym uwzględnieniem kontrastywnego podejścia do kwestii rozwodowych. Można zatem stwierdzić, że zostali wystarczająco przygotowani, aby sporządzić thumaczenie wyroków rozwodowych w obydwu kombinacjach językowych. Do celów badania zaaranżowano warunki porównywalne do egzaminu państwowego w zakresie przekładu pisemnego. Standardowy egzamin państwowy wynosi cztery godziny, podczas którego kandydaci tłumaczą cztery teksty - po dwa z każdej kombinacji językowej. W tym przypadku - z racji tego, że studenci mieli za zadanie przetłumaczyć dwa teksty, czas trwania egzaminu został podzielony na pół, a zatem studenci mieli do dyspozycji dwie godziny zegarowe podczas których mieli dokonać przekładu dwóch tekstów - polskiego oraz niemieckiego wyroku rozwodowego. Analogicznie do wymogów egzaminacyjnych mieli wyłącznie dostęp do przyniesionych przez siebie mono- i bilingwalnych słowników oraz glosariuszy, niezawierających jednak thumaczeń kompletnych partii tekstu.

Teksty źródłowe - polski i niemiecki wyrok rozwodowy - zaczerpnięto z publikacji autorstwa J. Iluka i A.D. Kubackiego (2006: 195-199) „Wybór polskich i niemieckich dokumentów do ćwiczeń translacyjnych / Auswahl polnischer und deutscher Dokumente für Translationsübungen”, zawierającej teksty paralelne najczęściej na-

\footnotetext{
${ }^{5}$ Wszyscy studenci wyrazili pisemną zgodę na przeanalizowanie ich przekładu do celów naukowych. W celu zapewnienia anonimowości wszystkie thumaczenia zostały podpisane wybranymi przez probantów pseudonimami.
} 
potykane w międzynarodowym obrocie prawnym, klasycznie używanej przez studentów kierunków językowych oraz kandydatów na tłumaczy przysięgłych. Kompatybilny klucz do niniejszej książki stanowi pozycja autorstwa K. Dahlmanns oraz A.D. Kubackiego pt. „Jak sporządzać tłumaczenia poświadczone dokumentów? / Wie fertigt man beglaubigte Übersetzungen von Urkunden an? - Kommentierte Übersetzungen zu den Texten aus der Auswahl polnischer und deutscher Dokumente für Translationsübungen" (2014), zawierająca wzorcowe thumaczenie poświadczone dokumentów zawartych w publikacji z 2006 roku - zgodnie z wszelkimi wymogami formalnymi i merytorycznymi dotyczącymi thumaczenia poświadczonego. $Z$ racji tego, że uznawane są one jako wzorcowe, wykorzystano je jako podstawę dla celów analizy porównawczej z thumaczeniami sporządzonymi przez studentów.

W tym miejscu należy zaznaczyć, że w ramach niniejszego artykułu nie analizowano ani nie klasyfikowano rozwiązań tłumaczeniowych ani błędów w tłumaczeniu studentów. Przedmiotem analizy było wyłącznie sprawdzenie, w jakim stopniu adepci sztuki przekładu zastosowali się do formalnych i merytorycznych zasad sporządzania thumaczenia poświadczonego.

Poniżej przedstawiono wyniki analizy porównawczej - oddzielnie dla kryteriów formalnych i merytorycznych. W przedstawionej niżej analizie zastosowano znak * jako oznaczenie cytatu thumaczenia studenckiego zawierającego niedostosowanie się do wybranego kryterium. Rozdział zakończony jest podsumowaniem wyników oraz wnioskami.

\subsection{Analiza: wymogi formalne i merytoryczne}

Jak wspomniano wyżej, zasady sporządzania tłumaczeń poświadczonych zostały obszernie opisane przez Polskie Towarzystwo Tłumaczy Przysięgłych i Specjalistycznych TEPIS w Kodeksie tlumacza przysiegłego z komentarzem 2011 (D. Kierzkowska 2011), następnie w Kodeksie zawodowym tlumacza przysięglego ${ }^{6}$ oraz opisane przez K. Dahlmanns i A.D. Kubackiego (2014: 37 i nast.), natomiast do celów niniejszej analizy świadomie zrezygnowano z części z nich - wykorzystano jedynie relewantne dla badania kryteria. Mianowicie, w kwestii wymogów formalnych świadomie zrezygnowano z analizy: wymogów dotyczących świadectw, dyplomów itp., odpisów oryginału oraz tekstów zawierających błędy, ponieważ nie znajdują one zastosowania $\mathrm{w}$ tekstach źródłowych użytych do celów niniejszej analizy. Nie wzięto również pod uwagę kryterium formalnego dotyczącego fragmentarycznego thumaczenia tekstu, ponieważ zadaniem badanych było dokonanie przekładu in extenso.

\subsubsection{Wymogi formalne}

Kryteria formalne dotyczące sporządzanie tłumaczenia poświadczonego, uproszczone $\mathrm{w}$ stosunku do zasad wymienionych przez TEPIS oraz K. Dahlmanns i

\footnotetext{
${ }^{6} \mathrm{http}$ ://tepis.org.pl/wp-content/uploads/Kodeks-zawodowy-tłumacza-przysięgłego-2018.pdf [Pobrano 10.01.2019].
} 
A.D. Kubackiego (2014:37 i nast.) przyjęte w niniejszej analizie, zostały przedstawione poniżej. Każda $\mathrm{z}$ nich została każdorazowo opatrzona symbolem $F$ - oznaczającego kryterium formalne.

1F. Każde thumaczenie poświadczone powinno zawierać na początku informację o kierunku tłumaczenia, podając jedynie język źródłowy przekładu, np. Beglaubigte Übersetzung aus dem Polnischen lub Ttumaczenie poświadczone z języka niemieckiego.

2F. Niezależnie od numeracji tekstu źródłowego, wszystkie strony tłumaczenia winny być ponumerowane.

3F. Tekst źródłowy powinien być przetłumaczony w całości (in extenso).

4F. Formuła poświadczająca powinna zostać napisana w odpowiedniej wersji językowej i umieszczona bezpośrednio pod tekstem przekładu. Należy w niej zawrzeć informację o zgodności thumaczenia $\mathrm{z}$ oryginałem oraz o formie oryginału (np. kopia, oryginał, faks, skan, wydruk komputerowy przedłożonego dokumentu $\mathrm{w}$ określonym języku). Ponadto winna być opatrzona danymi dotyczącymi tłumacza przysięgłego (jego imieniem i nazwiskiem, ewentualnie tytułem zawodowym, stopniem lub tytułem naukowym, numerem wpisania na listę thumaczy przysięgłych prowadzoną przez ministra sprawiedliwości), jego podpisem, numerem repertorium; informacją o liczbie stron przekładu, miejscu i dacie wykonania przekładu oraz miejscu i dacie wydania ewentualnego odpisu.

5F. Układ graficzny przekładu winien w jak największym stopniu odpowiadać układowi graficznemu tekstu oryginalnego.

6F. Tłumacz może umieścić swoje uwagi w formie przypisów w języku przekładu w nawiasach kwadratowych i zapisanych kursywą. Aby uniknąć każdorazowego informowania odbiorcy o tym, że dana uwaga pochodzi od thumacza, może on na początku przekładu zawrzeć informację, że wszystkie wzmianki zapisane w wyżej wymieniony sposób pochodzą od niego.

7F. Wszelkie elementy graficzne dokumentu oryginalnego winny zostać zwięźle opisane w tekście thumaczenia (np. godło państwowe, herb miasta, logo, znaki wodne, parafy, podpisy, dopiski odręczne, odciski wszelkich pieczęci, znaczki opłaty skarbowej, wykresy, diagramy itd.). W przypadku, gdy dany element graficzny jest nieczytelny, fakt ten powinien być odnotowany w przypisie.

$8 \mathrm{~F}$. W celu zapobieżenia próbom fałszowania zarówno oryginału, jak i tłumaczenia, w przypadku, gdy dana rubryka nie została uzupełniona, thumacz zobowiązany jest do umieszczenia w thumaczeniu znaku [-/-] lub wykonania adnotacji [nie wypetniono].

Poniżej przedstawiono wyniki analizy wyżej wymienionych kryteriów.

Ad) 1F: W przypadku wyroku niemieckiego tylko jeden probant poinformował o kierunku tłumaczenia. Natomiast w przekładzie polskiego wyroku kryterium to zostało spełnione przez pięciu badanych.

Ad) 2F: Strony thumaczenia zostały ponumerowane jedynie w przypadku wyroku polskiego - przez jednego studenta.

Ad) 3F: Co do zasady, wymogowi temu sprostali wszyscy studenci zarówno w 
przekładzie niemieckiego, jak i polskiego wyroku, tzn. wyroki zostały przetłumaczone w całości. Należy jednak zaznaczyć, że w kilku przypadkach doszło do opuszczenia treści znacznych fragmentów tekstu, np. całkowitego pominięcia informacji o kierunku tłumaczenia, numerze strony, opisu herbu kraju związkowego, informacji o prawomocności wyroku, miejscu i dacie wydania dokumentu niemieckiego, w innym przypadku tłumaczenie ograniczyło się do: „[pieczęć z godłem] Prawomocny od 19.08.20...”. Informacja o stanowisku pełnionym przez pracownika sądu (w oryginale: „Kirner, Justizangestellte als Urkundsbeamtin der Geschäftsstelle”) została całkowicie pominięta przez czterech probantów. Dane adresowe uczestnika postępowania (,[-/-] den Herrn [-/-], geboren am 28.08.19[-/-] 46325 Borken”) zostały częściowo pominięte przez dwóch adeptów (*,Panu..., urodzonemu 28.08.19...”). We fragmencie przetłumaczonym przez K. Dahlmanns/ A.D. Kubackiego jako: „Strony zgodnie twierdzą, że od maja 2004 r. żyją w stałej separacji przy zniesieniu wspólnoty domowej, a ich małżeństwo się rozpadło" jeden ze studentów pominął istotną część informacji, tłumacząc jako: *,Strony zgodnie przyznają, że od maja 2004 mieszkają oddzielnie". Warto również odnotować pojedynczy przypadek braku daty w przekładzie wyroku polskiego oraz braku informacji o stwierdzeniu autentyczności podpisu sędziego, kierownika sekretariatu i pieczęci urzędowej.

Ad) 4F: Żadne tłumaczenie wyroku niemieckiego nie zostało opatrzone formuła poświadczającą. Natomiast w przypadku wyroku polskiego formuły takowej nie dołączyła dwójka badanych.

Ad) 5F: Układ graficzny został we wszystkich przypadkach wiernie przejęty w przekładzie.

Ad) 6F: Przypisy tłumacza w większości przypadków zastosowano poprawnie, chociaż kursywa została zastosowana jedynie w przypadku niektórych badanych (tylko jeden z probantów zastosował się do nich w obydwu przekładach). Warto odnotować błędy związane z pisownią nazw własnych, np. nazwisko zawarte w wyroku niemieckim „Schüling” zostało błędnie przepisane przez dwójkę badanych jako *,Schaltag“ oraz *,Schutung“, następnie nazwisko „Kirner” zostało przepisane jako *,Kirnor”, zaś w przypadku wyroku polskiego - „Barczyk” przetłumaczono jako *,Wańczyk”, a „Kiercz” jako *,Kiertz”. Niniejsze przykłady winny być opatrzone stosownym przypisem o braku czytelności.

Ad) 7F: Kryterium to, podobnie jak 6F, przysporzyło probantom trudności. Wszystkie elementy graficzne niemieckiego wyroku zostały poprawnie opisane przez trzech probantów, zaś polskiego - przez czterech badanych. Pozostali studenci sprostali temu wymogowi tylko częściowo. Szczególnie problematyczne okazało się poprawne opisanie odcisków pieczęci wraz z ich wyglądem oraz szczegółową lokalizacją, jak również podpisów (także uwzględniając stopień ich czytelności) oraz herbu kraju związkowego. W tym miejscu należy zaznaczyć, że zawarty w niemieckim wyroku herb kraju związkowego został rozpoznany i poprawnie opisany tylko przez jednego probanta.

Ad) 8F: Zasada ta nie została zastosowana przez żadnego z probantów. Nieuzupełnione rubryki (również takie, które zostały zakryte przez autorów publikacji z 
uwagi na ochronę danych osobowych) nie zostały w żadnym wypadku opatrzone poprawną adnotacją ([-/-] lub [brak informacji]), a jedynie opatrzone innymi znakami graficznymi, tj. zwielokrotniony wielokropek lub ,

\subsubsection{Wymogi merytoryczne}

W zakresie kryteriów merytorycznych uwzględniono niżej wymienione zasady (zob. K. Dahlmanns/ A.D. Kubacki 2014: 44 i nast.). Każda z nich została każdorazowo opatrzona symbolem $M$ - oznaczającego kryterium merytoryczne.

1M. A) Przy tłumaczeniu odmienionych nazw własnych na język niefleksyjny powinny być zapisane $\mathrm{w}$ mianowniku liczby pojedynczej.

1M. B) Przy tłumaczeniu nazw własnych z języka niefleksyjnego na fleksyjny, zapisuje się je w odpowiednim przypadku. W celu uniknięcia wątpliwości, dobrą praktyką jest zapisanie $\mathrm{w}$ formie przypisu mianownika liczby pojedynczej nazwy własnej w przy jej pierwszym wystapieniu.

2M. Znaki diakrytyczne nazw własnych powinny zostać zachowane w każdym kierunku thumaczenia.

3M. Dane adresowe osób lub instytucji podlegające funkcji komunikacyjnej dla organów pocztowych należy pozostawić w oryginale (w razie konieczności można je transkrybować lub transliterować). Jeżeli tego typu dane stanowią część zdania i nie pełnią wyżej wymienionej funkcji, mogą zostać przetłumaczone.

4M. Nazwy urzędów powinny zostać przetłumaczone, przy czym przy ich pierwszym wystąpieniu w tekście przekładu koniecznie należy podać ich brzmienie oryginalne w nawiasie kwadratowym. Obowiązek ten nie występuje w przypadku aktów prawnych, jednak w celu uniknięcia niepożądanych wątpliwości, dobrze jest zastosować w tłumaczeniu przymiotnik dookreślający kraj pochodzenia danego aktu, np. niemiecki Kodeks cywilny - polnisches Zivilgesetzbuch.

5M. Nazwy miejscowości i obiektów fizjograficznych pozostawia się w brzmieniu oryginalnym. Jeżeli istnieje oficjalny ekwiwalent $w$ języku docelowym - również należy go użyć, jednak - jeżeli odpowiednik w języku docelowym jest rzadko używany - przy pierwszym jego wystąpieniu w tekście należy podać brzmienie oryginalne $\mathrm{w}$ formie przypisu thumacza.

6M. A) Skróty i skrótowce powinny zostać przetłumaczone w pełnym brzmieniu.

6M. B) Skróty powszechnie znane można przetłumaczyć bez ich rozwijania, o ile ich ekwiwalenty istnieją w języku docelowym, np. „itp.” - „u. Ä.”.

6M. C) W przypadku, gdy tłumacz nie jest w stanie rozszyfrować skrótu lub skrótowca, powinien on być pozostawiony $\mathrm{w}$ oryginale oraz opatrzony przypisem tłumacza w języku docelowym „skrót nieznany”.

7M. Liczby rzymskie i/lub arabskie należy dostosować do konwencji języka docelowego, np.: VII Wydział Cywilny -7 . Zivilabteilung.

8M. Dane liczbowe, które w oryginale zostały zapisane słownie, należy również oddać w języku docelowym w sposób słowny. 
9M. Styl autora powinien zostać w miarę możliwości wiernie zachowany w thumaczeniu.

Poniżej przedstawiono wyniki analizy wyżej wymienionych kryteriów.

Ad) 1M: Nazwy własne zostały w przeważającej większości poprawnie odmienione (np. w przekładzie na polski fragmentu ,durch den Richter am Amtsgericht Pohlmann” przez jednego z probantów: „przez sędziego Sądu Rejonowego Pohlmanna") oraz zapisane w mianowniku liczby pojedynczej w odwrotnym kierunku (np. „zugunsten der Rechtsanwaltkanzlei von Anwalt Jerzy Bossowski”). Jednak w przypadku dwójki probantów mamy do czynienia z nieodmienionym nazwiskiem: *,,w osobie sędziego Pohlmann z Sądu Rejonowego orzekł” oraz *,w osobie Sędziego Pohlmann (...) orzekł, co następuje" Jednakże, jak już zaznaczono wyżej, w niektórych fragmentach probanci nie ustrzegli się błędów związanych z pisownią nazw własnych - bez zaznaczenia w formie przypisu o trudności z odczytaniem oryginału.

Ad) 2M: Znaki diakrytyczne w nazwach własnych zostały zachowane - oprócz dwóch przypadków - w przekładzie niemieckiego wyroku. Jak wspomniano wyżej, nazwy własne nie zostały poprawnie przepisane: nazwisko „Schüling” zostało podane w thumaczeniu na język polski jako: *,Schaltag”, *,Schutung”.

Ad) 3M: Dane adresowe nie pojawily się w wyroku polskim, natomiast w wyroku niemieckim zostały przetłumaczone (co w tym przypadku było dozwolone, ponieważ nie były to dane do celów pocztowych), jednak tylko w sposób częściowy lub wybiórczy, np. poprzez nieuwzględnienie części składowej adresu. Interesującym przykładem jest thumaczenie fragmentu o danych adresowych: „,der Frau (...) geboren am (...) Weg (...) 46325 Borken-Weseke”. Słowo „Weg”, które powinno być zostawione w oryginale, jednak żaden z probantów nie wybrał takiej strategii. Pięcioro studentów pominęło w thumaczeniu słowo „Weg”, natomiast inni probanci przethumaczyli to jako: *,droga" lub *,nie stawiła się".

Ad) 4M: Nazwy własne instytucji powinny być zarówno przetłumaczone, jak i podane $\mathrm{w}$ formie oryginalnej przy ich pierwszym pojawieniu się $\mathrm{w}$ tekście przekładu ${ }^{7}$. W przypadku thumaczenia niemieckiego wyroku nazwy instytucji oraz aktów prawnych (w przypadku których ww. zasada nie jest obligatoryjna, lecz zalecana) zostały zarówno przetłumaczone, jak i opatrzone nazwą oryginalną (np. „Sąd Rejonowy Borken [Amtsgericht Borken]”, ,niemieckiego Kodeksu cywilnego [BGB - Bürgerliches Gesetzbuch]", ,niemieckiego Kodeksu postępowania cywilnego [ZPO - Zivilprozessordnung]"). Należy jednak zaznaczyć, że niektórzy probanci popełnili błędy w pisowni wielkich liter nazw aktów prawnych, wedle której tylko pierwszy człon winien być napisany wielką literą (np. („Kodeks cywilny“, a nie, jak w przypadku dwojga probantów *,Kodeks Cywilny“ lub *,kodeks cywilny“). Podobnie, studenci popełniali błędy w pisowni nazw sądów, których obydwa człony w języku polskim powinny być pisane wielką literą (np.*,sądu rejonowego“ zamiast „Sądu Rejonowego”). Natomiast w przekładzie wyroku polskiego na język niemiecki większość

\footnotetext{
${ }^{7} \mathrm{~W}$ niniejszym artykule nie analizuje się stosowności tłumaczenia nazw instytucji. Więcej na ten temat: A.D. Kubacki $(2009,2014)$.
} 
probantów nie spełniła omawianego tu wymogu (czterech probantów). Tylko niektórzy opatrzyli nazwę instytucji jej oryginalnym brzmieniem w formie przypisu thumacza (np. „Regionalgericht Katowice [Sad Okręgowy w Katowicach]”).

Ad) 5M: W tym przypadku nazwy miast zostały podane w sposób poprawny $-\mathrm{z}$ jednym wyjątkiem - Sąd Okręgowy w Katowicach został przetłumaczony jako: *,Bezirksgericht Kattowitz“. Zastosowano zatem jedynie niemiecką nazwę miasta polskiego bez podania jej nazwy oryginalnej. Zgodnie z niniejszym kryterium zalecane jest podane dwóch nazw (w tym przypadku: Katowice [Kattowitz]), zwłaszcza zważywszy na fakt, że stanowi część składową nazwy instytucji sądu.

Ad) 6M: Kryterium to, podobnie jak 4M, przysporzyło studentom największe trudności. Niemniej jednak tylko dwoje $\mathrm{z}$ nich nie sprostało temu zadaniu, podczas gdy reszta zastosowała się do niego w przeważającej części. W zestawieniu przekładu dwóch dokumentów - tłumaczenie niemieckiego wyroku wypadło korzystniej niż polskiego. W niektórych przypadkach nie zostały jednak poprawnie rozwinięte, co z pewnością utrudniłoby recepcję odbiorcom docelowym (np. *„§ 1565 I 1 BGB” zamiast „zgodnie z $§ 1565$ I 1 niemieckiego Kodeksu cywilnego [BGB - Bürgerliches Gesetzbuch]”, *,PLA Schaltag” oraz *,PLA: Schutung” zamiast „,adwokat Schüling” lub w przypadku polskiego wyroku u trzech badanych: *,Vorsitzende SSO Ewa” zamiast "die Vorsitzende am Bezirksgericht Ewa”). We fragmentach zawierających skrót „RA” (Rechtsanwalt) lub „SSO” (Sędzia Sądu Okręgowego) powinny być one rozwinięte. Jednak jeżeli probant nie zna tego skrótu, winien on dodać stosowny przypis w języku docelowym, informujący o tym fakcie.

Ad) 7M: Wymóg dostosowania pisowni liczb do konwencji języka docelowego nie ma zastosowania $\mathrm{w}$ wyroku niemieckim. W przypadku wyroku polskiego czterech probantów nie zastosowało się do tego kryterium i przejęło pisownię z języka oryginału, np. „XVII Wydział Cywilny Rodzinny” nie został przetłumaczony jako "17. Zivil- und Familienabteilung”, lecz jako *,XVII Zivil- und Familienabteilung” (dwoje badanych) lub *,XVII. Zivil- und Familienabteilung” (jeden probant), które jest swoistą hybrydą konwencji zastosowania pisowni liczb rzymskich i arabskich.

Ad) 8M: Także w tym wypadku kryterium ma zastosowanie wyłącznie dla drugiego wyroku (w wyroku niemieckim nie zastosowano słownej pisowni liczb). Poprawnie zapisali liczby wszyscy probanci $\mathrm{z}$ wyjątkiem jednego, chociaż $\mathrm{w}$ innych przekładach zaobserwowano błędy pisowni (np. *,400,00 Złotys /vier Hundert/” zamiast „/vierhundert/”; *,1600 zl /Ein Tausend Sechs Hundert/” zamiast ,/eintausendsechshundert/").

Ad) 9M: Rejestr stylistyczny obydwu wyroków zostały zachowany w większości przypadków, jednak w niektórych fragmentach można zaobserwować wyrażenia, które go obniżają. Jako przykład usterek stylistycznych może służyć przetłumaczenie „Heiratsregister-Nummer” (,numer w rejestrze małżeństw“) jako: *,małżeństwo o numerze rejestracyjnym”, czy fragmentu „Die Kostenentscheidung folgt aus $\S 93$ a ZPO” („Podstawę orzeczenia o kosztach sądowych stanowi § 93a niem. Kodeksu postępowania cywilnego”) jako: *,Orzeczenie o kosztach wypływa z § 93 a niem. kodeksu postępowania cywilnego". 


\section{Podsumowanie}

Na podstawie zgromadzonych danych można stwierdzić, że badana grupa studentów spełniła relatywnie dużą liczbę kryteriów formalnych i merytorycznych dotyczących thumaczenia poświadczonego. Wszystkie thumaczenia zostały sporządzone in extenso, zaś ich układ graficzny został wiernie zachowany. Większość z nich została również opatrzona przypisami tłumacza w nawiasie kwadratowym. Przeważnie zastosowano również znaki diakrytyczne oraz podano oryginalną nazwę miejscowości.

Największe trudności w zakresie wymogów formalnych, które ujawniły się w toku realizacji pilotażowego projektu, związane były z informacją o kierunku tłumaczenia, numerowaniem stron, umieszczeniem formuły poświadczającej oraz poprawnym opisywaniem niewypełnionych rubryk. Wysoce problematyczne okazało się również poprawne stosowanie przypisów tłumacza oraz właściwy opis elementów graficznych. Natomiast pod względem wymogów merytorycznych adepci najczęściej mieli problemy z poprawnym zapisaniem danych adresowych, poprawnym opisie nazw instytucji oraz aktów prawnych, przetłumaczeniu skrótów i skrótowców, zachowaniu rejestru stylistycznego, a także pisowni liczb.

Odstępstwa od wymogów formalnych i merytorycznych mogą wynikać z faktu, że thumaczenia zostały sporządzone pod presją czasu, co prawdopodobnie przyczyniło się do pominięcia znacznych partii tekstu, błędów pisowni czy też nieumieszczenia informacji obligatoryjnych, tj. informacja o kierunku thumaczenia, formuły poświadczającej czy przypisów tłumacza. Mogło się to również przyczynić do braku dokonania korekty własnego thumaczenia, zarówno pod względem jakości przekładu, jak i poprawności językowej. Nie można jednak wykluczyć, że odstępstwa od zasad sporządzania tłumaczenia poświadczonego mogły wynikać z nieznajomości określonych kryteriów. Może o tym świadczyć konsekwencja w niestosowaniu niektórych zasad, przede wszystkim dotyczących numerowania stron, opisu niewypełnionych rubryk, czy też poprawnego podawania danych adresowych.

Odnośnie do kryteriów merytorycznych warto zaznaczyć, że podawanie thumaczenia oraz oryginalnej nazwy instytucji (oraz - fakultatywnie - aktów prawnych) jest szczególnie istotne ze względu na uniknięcie wszelkich wątpliwości po stronie odbiorców docelowych tłumaczenia. Unika się w ten sposób fałszywego przekonania co do pochodzenia czy tożsamości instytucji czy aktów prawnych. Probanci, którzy nie zastosowali się do tego kryterium powinni być świadomi potencjalnych skutków takiego przekładu. W niektórych fragmentach nazwy określonych instytucji lub aktów prawnych nie zostały opatrzone ich oryginalną nazwą $\mathrm{w}$ formie przypisu tłumacza $\mathrm{w}$ nawiasie kwadratowym przy pierwszym wymienieniu w tekście thumaczenia. Może to w konsekwencji prowadzić do niejasności, które zwłaszcza w przypadku thumaczenia poświadczonego uchodzą za wysoce niepożądane. Wszelkie wątpliwości co do interpretacji tekstu thumaczenia mogą spowodować daleko idące konsekwencje.

W przypadku konwencji stosowania liczb w formie arabskiej lub rzymskiej dochodziło do braku dostosowania do konwencji języka docelowego, co może wynikać z braku wiedzy o konwencji typowej dla określonego języka. Natomiast zastosowana przez probantów błędna pisownia liczb w przekładzie na język niemiecki wynikać 
może z tego, że liczby zapisuje się częściej cyfrowo niż słownie. Warto również zauważyć, że błędna pisownia przypomina angielską konwencję pisania liczb. Z racji tego, że drugim językiem dla badanych studentów jest angielski, możliwe, że doszło do interferencji językowych, co jednak należałoby poprzeć szerzej zakrojonym badaniem $^{8}$.

W zakresie kryteriów formalnych z całą pewnością należy wspomnieć o niejasnościach wynikających z niewłaściwego opisu nieznanych, czy trudnych do opisania skrótów i skrótowców. Warto odnotować, że wielu studentów nie zna typowych dla dokumentów prawniczych (np. związanych z nazwami funkcji i stanowisk służbowych, $\mathrm{tj}$. stanowisko sędziego czy adwokata), co świadczy o deficytach wiedzy w tej dziedzinie. $\mathrm{W}$ analizowanym badaniu doszło również do nieudanych prób rozszyfrowania treści odcisków pieczęci. Mając na uwadze fakt, że dane osobowe zawarte na odcisku pieczęci były trudne do odczytania, zamiast przedstawionych wyżej prób rozszyfrowania winna była znaleźć się uwaga w formie przypisu, informująca o nieczytelności danych. W celu uniknięcia wysoce niepożądanych niejasności, w przypadku trudnych do odczytania fragmentów tekstu czy nieznanych skrótów i skrótowców należy opatrzyć je stosowną uwagą thumacza (np. [nieczytelny podpis], [nieznany skrót]). Kryterium to nie zawsze zostało spełnione przez studentów.

Per analogiam, zastosowane przez studentów oznaczenia tj. zwielokrotniony wielokropek lub , " w celu opisania niewypełnionych rubryk mogą jednak okazać się niezrozumiałe, a nawet potencjalnie wprowadzające w błąd odbiorcę. W takim przypadku zamieścić znak [-/-] lub adnotację [nie wypetniono] w formie przypisu thumacza. Nie zawsze bowiem wiadomo, czy chodzi o jedną lub więcej cyfr lub wyrazów. Wszelkie niejasności nie powinny mieć miejsca w tego rodzaju przekładzie. Ponadto zaś należy unikać wszelkich okoliczności, w których mogłoby dojść do próby fałszowania oryginału i/lub przekładu. Na tę kwestię należy zatem zwracać szczególną uwagę w dydaktyce tego rodzaju przekładu.

W niektórych fragmentach doszło również do usterek stylistycznych. Adepci przekładu powinni być świadomi, że niezachowanie rejestru stylistycznego przynależnego danemu gatunkowi tekstów może prowadzić do niepożądanych reakcji odbiorcy docelowego.

Znaczne trudności sprawił studentom także opis wszelkich elementów graficznych tj. odciski pieczęci, podpisy itp. Zawarty w niemieckim wyroku herb kraju związkowego zostało poprawnie rozpoznane jedynie przez jednego studenta. Jak wspomniano wcześniej, probanci nie mieli dostępu do Internetu, stąd prawdopodob-

\footnotetext{
${ }^{8}$ Należy mieć na uwadze, że grupą badaną byli studenci kierunku wymagającego biegłego posługiwania się dwoma językami obcymi (w tym przypadku niemieckim i angielskim), ponadto zaś w momencie przeprowadzenia badania wszyscy studenci uczęszczali także na lektorat z innych języków obcych. Można przypuszczać, że mogło dojść do interferencji językowych, co w konsekwencji mogło przyczynić się do niektórych zaobserwowanych zjawisk negatywnie wpływających na jakość tłumaczenia (np. błędów w pisowni liczb czy dostosowania konwencji pisowni liczb do języka docelowego). Hipotezę tę można jednak poprzeć wyłącznie poprzez przeprowadzenie analogicznego badania na bardziej reprezentatywnej liczbie studentów.
} 
nie informacja ta została pominięta w przekładzie. Studenci prawdopodobnie nie przewidzieli tego rodzaju trudności, wobec czego nie przygotowali się na ewentualność potrzeby przyswojenia tego rodzaju informacji. W zakresie wiedzy o realiach krajów niemieckojęzycznych uwidaczniają się zatem deficyty. Przykład ten świadczy również o tym, że mimo relatywnie gruntownego przygotowania do wykonania thumaczenia poświadczonego, studenci mogą napotkać niespodziewane dla nich trudności, które mogą zdarzyć się również podczas państwowego egzaminu dla kandydatów na thumaczy przysięgłych, a także w realnej sytuacji zawodowej.

Podsumowując, należy stwierdzić, że studenci w sposób powierzchowny sprostali większości wymogów formalnych i merytorycznych dotyczących sporządzania tłumaczenia poświadczonego. Występujące deficyty świadczą o jeszcze nieugruntowanej kompetencji językowej (zarówno w języku polskim, jak i niemieckim) oraz niepełnej wiedzy dotyczącej wyżej wymienionych kryteriów lub jej braku, co z kolei świadczy o konieczności zwrócenia szczególnej uwagi pedagogów w tym względzie. Istotne jest również zwracanie uwagi uczącym się na potencjalne konsekwencje błędów oraz niedopełnienia formalnych i merytorycznych zasad sporządzania thumaczenia poświadczonego - nie tylko przez wzgląd na potencjalnie ujemny wynik egzaminu państwowego, ale przede wszystkim ze względu na skutki błędnego przekładu.

Opisany wyżej projekt miał charakter pilotażu. Ze względu na interesujące wnioski oraz w celu uzyskania bardziej reprezentatywnych i wiarygodnych wyników będzie w przyszłości poszerzony o większą grupę badanych. Na tym etapie niniejszy artykuł może stanowić podstawę szerzej zakrojonych badań oraz wstępne wskazówki dydaktyczne dla nauczycieli przekładu prawniczego oraz dla kandydatów na tłumaczy przysięgłych.

\section{Bibliografia}

Dahlmanns, K./ A.D. Kubacki (2014), Jak sporzadzać ttumaczenia poświadczone dokumentów? / Wie fertigt man beglaubigte Übersetzungen von Urkunden an? Chrzanów.

Fleck, K.E.W. (1999), Urkundenübersetzung, (w:) M. Snell-Hornby i in. (red.), Handbuch Translation. Tübingen.

Iluk, J./ A.D. Kubacki (2006), Wybór polskich i niemieckich dokumentów do ćwiczeń translacyjnych/Auswahl polnischer und deutscher Dokumente für Translationsübungen. Warszawa.

Jessnitzer, K. (1992), Dolmetscher: Ein Handbuch für die Praxis der Dolmetscher, Übersetzer und ihrer Auftraggeber im Gerichts-, Beurkundungs- und Verwaltungsverfahren. Köln-Berlin-Bonn-München.

Kierzkowska, D. (red.) (2011), Kodeks tlumacza przysięglego z komentarzem 2011. Warszawa.

Kierzowska, D. i in. (2018), Kodeks zawodowy tlumacza przysięglego. Polskie Towarzystwo Tłumaczy Przysięgłych I Specjalistycznych TEPIS. Warszawa. 
(URL http://tepis.org.pl/wp-content/uploads/Kodeks-zawodowy-thumacza-przysięgłego-2018.pdf). [Pobrano 12.01.2017].

Kubacki, A.D. (2009): Fehler in der Fachübersetzung der Kandidaten für einen staatlich vereidigten Übersetzer, (w:) „Zeszyty Naukowe Instytutu Neofilologii i Komunikacji Społecznej" 2 (Philologische Ostsee-Studien), 11-28.

Kubacki, A.D. (2010), Zum Beruf eines vereidigten Übersetzers in Polen, (w:) P. Bąk/ M. Sieradzka/ Z. Wawrzyniak (red.), Texte und Translation. (Danziger Beitrage zur Germanistik, t. 29). Frankfurt am Main, 274-280.

Kubacki, A.D. (2012): Ttumaczenie poświadczone. Status, ksztatcenie, warsztat i odpowiedzialność tlumacza przysięgłego. Warszawa.

Kubacki A.D. (2014), Błąd krytyczny w tlumaczeniach poświadczonych, (w:) „Lingua Legis" 22. 63-71.

Nartowska, K. (2015): Gerichtsdolmetschen in Polen. (w:) UNIVERSITAS Austria, Berufsverband für Dolmetschen und Übersetzen 4/15. (URL https://depot.ceon.pl/ bitstream/handle/123456789/9705/nartowska_2015_gerichtsdolmetschen\% 20in\%20polen.pdf?sequence= 1\&isAllowed=y). [Pobrano 12.01.2017].

Pisarska, A./ T. Tomaszkiewicz (1998), Wspótczesne tendencje przekładoznawcze. Podręcznik dla studentów neofilologii. Poznań.

Rozporządzenie Ministra Sprawiedliwości z dnia 24 stycznia 2005 r. w sprawie szczegółowego sposobu przeprowadzania egzaminu na thumacza przysięgłego (Dziennik Ustaw nr 15, poz. 129). (URL http://prawo.sejm.gov.pl/ isap.nsf/ DocDetails. xsp?id= WDU20050150129). [Pobrano 10.01.2019].

Ustawa z dnia 25 listopada 2004 r. o zawodzie thumacza przysięgłego (Dziennik Ustaw $\mathrm{nr}$ 273, poz. $2702 \mathrm{z}$ późniejszymi zmianami). (URL http://prawo.sejm.gov.pl/isap.nsf/DocDetails.xsp?id=wdu20042732702). [Pobrano 10.01.2019]. 